\title{
Plasma Progesterone in Reindeer in Relation to Ovariectomy and Hysterectomy
}

\author{
By Ø. V. Sjaastad, A. K. Blom, R. Austad and E. O. Øen
}

Department of Physiology and Nutrition and Department of Obstetrics, Norwegian College of Veterinary Medicine, Oslo, Norway.

\begin{abstract}
Sjaastad, Ø. V., A. K. Blom, R. Austad and E. O. Øen: Plasma progesterone in reindeer in relation to ovariectomy and hysterectomy. Acta vet. scand. 1990, 31, 45-51. - Four semi-domesticated reindeer were ovariectomized and 3 both ovariectomized and hysterectomized, 30-70 days before expected parturition. Anaesthesia with etorphine/propyonylphenthiazine was followed by an increase in the plasma concentration of progesterone of peripheral blood. The concentration of progesterone returned to pre-anaesthetic values before ovariectomy. Ovariectomy did not result in any substantial change in the plasma progesterone concentration within an observation period of 35-120 min. Hysterectomy was followed by a marked decrease in peripheral plasma progesterone within $60 \mathrm{~min}$. The progesterone concentration in ovarian venous blood was slightly higher than the jugular venous blood in 1 animal and 150 and 400 times higher in the 2 other animals examined. Thus, despite lack of marked changes of progesterone in jugular venous blood upon ovariectomy, it is concluded that the ovaries are a major production site of progesterone in pregnant reindeer.

The progesterone in uterine venous blood was close to that in the jugular vein in 1 animal, and slightly higher in 2 others. This observation, and the maintenance of pregnancy in spite of ovariectomy in 2 out of 4 animals, point to the foeto-placental unit as an additional source of progesterone production.
\end{abstract}

progesterone; plasma; ovariectomy; hysterectomy; reindeer.

\section{Introduction}

The balance between the ovaries and the foeto-placental unit in the production of progesterone during late pregnancy varies widely between species. In sheep (Linzell \& Heap 1968, Fylling 1970), guinea-pig (Heap \& Deanesly 1966) and most cows (Erb et al. 1967, Lindell et al. 1981), sufficient progesterone in produced extra-ovarially to maintain pregnancy. In primates, placenta is the only production site of importance in late pregnancy (Diczfalusy \& Borell 1961, Neill et al. 1969), while in goats (Linzell \& Heap 1968, Blom \& Lyngset 1971), pigs (Heap 1972) and also in 2 wild-living ruminant species, the red deer and the white- tailed deer (Kelly et al. 1982, Plotka et al. 1982) only ovarial production of progesterone has been demonstrated.

Studies of hormonal changes in reindeer during pregnancy indicated that at least part of the progesterone during late pregnancy is produced extra-ovarially (Rehbinder et al. 1981, Blom et al. 1983). The objective of the present study was to examine whether the indication of extra-ovarial formation of progesterone could be confirmed by ovariectomy and hysterectomy.

\section{Material and methods}

Eight semi-domesticated pregnant reindeer, expected to calve in the middle of May, were 
transported from a herd at Røros to the Norwegian College of Veterinary Medicine March 6th. Weights at arrival were estimated to be approximately $60 \mathrm{~kg}$. The animals were kept in an outdoor pen of $10 \times 10$ $\mathrm{m}$ and fed pelleted reindeer food with a crude protein concentration of $13.7 \%(\mathrm{Ja}$ cobsen \& Skjenneberg 1979) and lichen at appetite. The consumption of pellets was minimal the first days.

Three weeks after arrival 1 animal (no 4) aborted spontaneously.

During the period prior to surgery, jugular venous blood was drawn at intervals into heparinized vacutainers. Five animals were subjected to surgery about 50-70 days before expected parturition, 2 only ovariectomized and 3 also hysterectomized. The remaining 2 were ovariectomized about 30 days before expected parturition. The animals were starved overnight and immobilized by a combination of etorphine (M99), 2-4 mg and propyonylphenthiazine (Combelen ${ }^{\circledR}$ ), 6-12 mg, given intramuscularly. In 3 animals, supplementary injection of etorphine (1-2 $\mathrm{mg}$ /Combelen had to be given during the operation. An indwelling catheter was inserted into he jugular vein and blood samples were taken at preset points of time.

The left flank was shawed and Lidocainadrenalin was used as a local anesthetic. The uterus was exposed by a flank incision. In 3 of the animals, blood samples were taken from the ovarian and the uterine vein on the gravid side before ovariectomy. The hilus of the ovaries were ligated and the ovaries excised in all animals. The incision was closed, whereupon the animals were given an etorphine antidot, diprenorphine, 45-60 min. after ovariectomy.

The blood samples were centrifuged within short time of sampling and the plasma stored at $-20^{\circ} \mathrm{C}$ until analyzed. Progesterone was measured by radioimmunoassay as de- scribed by Schanbacher (1979), with some modifications. Twenty $\mu \mathrm{l}$ plasma and $100 \mu \mathrm{l}$ phosphate buffer were heated to $60^{\circ} \mathrm{C}$ for 15 min prior to the addition of tracer and antiserum. To separate bound and free progesterone, dextran coated charcoal was used. Antiserum to progesterone was bought from Calbiochem-Behring. Specificity of the antiserum is given in Biochemical and Immunochemical Catalogue, 1984, CalbiochemBehring. The detection limit of the method, as read from the standard curves, was about $1.5 \mathrm{nmol} / \mathrm{l}$. Analyses of a control plasma, run at intervals, deviated with less than $8 \%$ from the mean value.

\section{Results}

Only a few blood samples were drawn in the period prior to surgery. Although some fluctuations were observed, there was a general decrease in plasma progesterone from the day after arrival until the day of operation (Figs. 1 and 2).

Capturing of the animals followed by injection of etorphine/propyonylphenthiazine resulted in a transient increase in plasma progesterone in all animals. In all animals, except 1 (Fig. 1a), the concentration of progesterone returned to pre-medication values before ovariectomy was performed. During operation, rectal temperature increased to $39.8-43^{\circ} \mathrm{C}$. The animals at times exhibited a varying degree of tremor and panting despite an anaesthesia which seemed to be fairly deep.

\section{Ovariectomy}

In the animals in which plasma progesterone returned to pre-anaesthetic values before ovariectomy, the hormone levels did not change much during the first $30-15 \mathrm{~min}$ after ovariectomy (e.g. Figs. 1b, $2 \mathrm{a} \& 2 \mathrm{~b}$ ). In the course of the following days, plasma 

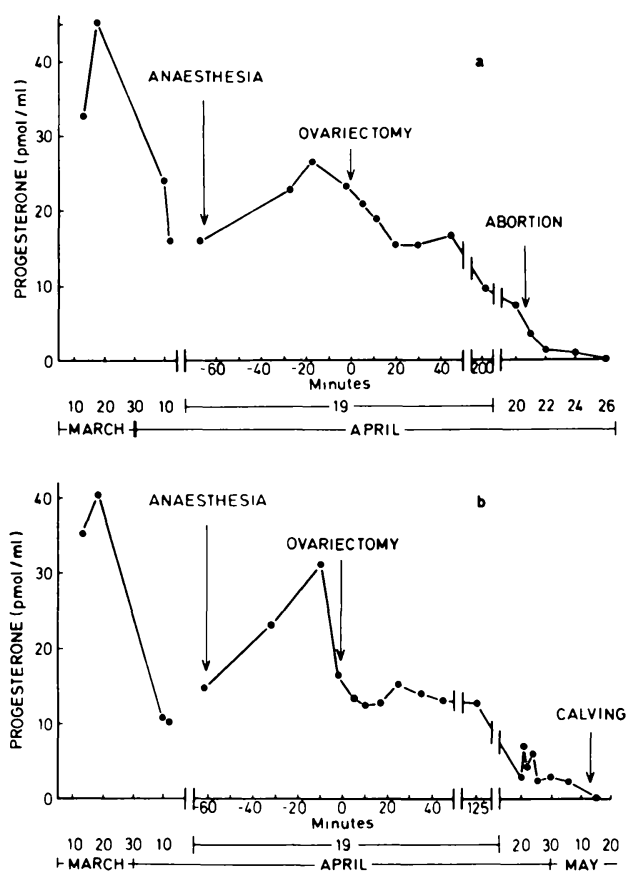

Figure 1. Progesterone in peripheral plasma in 2 reindeer (a: no. 2, b: no. 5) subjected to ovariectomy about 30 days before expected parturition.

progesterone fell to values of 3-6 nmol/l (e.g. Figs. $1 \mathrm{a} \& 1 \mathrm{~b}$ ).

One animal (no. 2, Fig. 1a) aborted a live calf 2 days after ovariectomy. Plasma progesterone was $7.3 \mathrm{nmol} / \mathrm{l}$ at the day of abortion. Another animal (no. 1) died 14 days after the operation. Autopsy indicated peritonitis to be the most probable cause of death. The post-mortem examination also indicated that the foetus had died within a few days after operation. Another animal (no. 3) died 1 month after ovariectomy. Autopsy indicated peritonitis as the cause of death, despite intensive treatment with antibiotics. In this case the foetus appeared to have been alive until the death of the mother. The fourth animal (no. 5, Fig. 1b) calved at term, 26 days after ovariectomy.
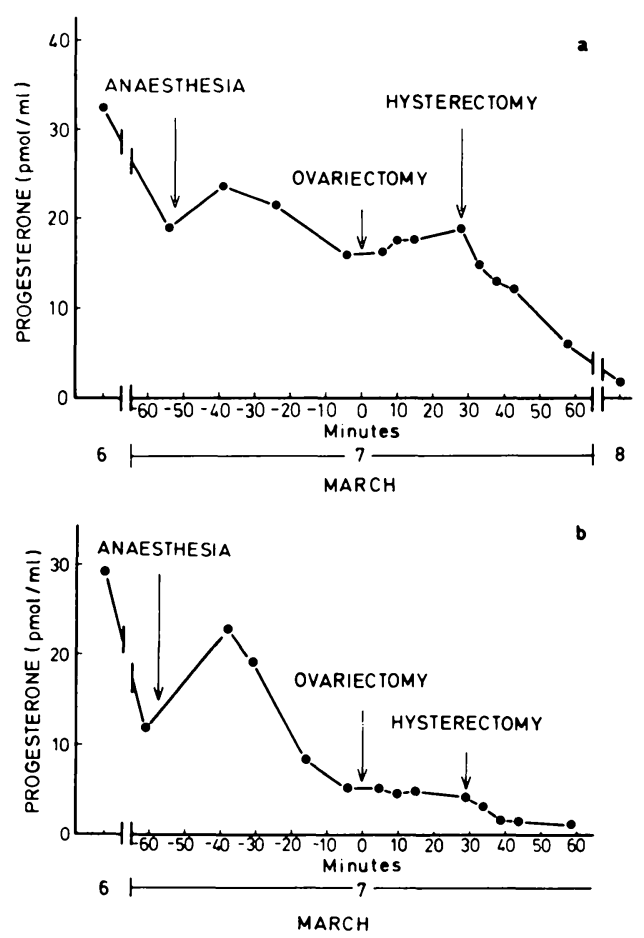

Figure 2. Plasma progesterone of peripheral blood in 2 reindeer (a: no. 6, b: no. 7) subjected to ovariectomy and hysterectomy about 70 days before expected parturition.

Ovariectomy and hysterectomy

In the 3 animals (nos. 6-8) in which both ovariectomy and hysterectomy were performed, plasma progesterone was fairly stable during the $30 \mathrm{~min}$ between ovariectomy and hysterectomy. During the first $60 \mathrm{~min}$ following hysterectomy, the concentration of progesterone in plasma of peripheral blood decreased substantially (Figs. 2a \& 2b).

\section{Uterine and ovarian blood samples}

In 1 animal progesterone in ovarian venous blood was slightly higher than in peripheral blood, and in the 2 others $150-400$ times higher (Table 1). Progesterone in plasma of uterine venous blood was close to that of ju- 
Table 1. Progesterone concentrations in plasma of jugular, uterine and ovarian venous blood immediately before ovariectomy in 3 reindeer. The samples were taken about $60-70$ days before expected parturition.

\begin{tabular}{lccc}
\hline \multirow{2}{*}{$\begin{array}{l}\text { nnimal } \\
\text { no. }\end{array}$} & \multicolumn{3}{c}{ Progesterone (nmol// plasma) } \\
\cline { 2 - 4 } & Jugular vein & Uterine vein & Ovarian vein \\
\hline 6 & 15.9 & 15.3 & 26.4 \\
7 & 5.1 & 9.2 & 812 \\
8 & 6.1 & 9.9 & 2675 \\
\hline
\end{tabular}

gular venous blood in 1 animal and slightly higher in the 2 remaining.

\section{Ovaries}

In all the animals subjected to surgery, the ovaries of the gravid horn had a corpus luteum, $10-12 \mathrm{~mm}$ in diameter. In 2 of the animals, an additional small corpus luteum, 5-6 $\mathrm{mm}$ in diameter was also observed. In none of the animals did the ovary on the non-gravid side contain any corpora lutea.

\section{Discussion}

At the time of arrival at the veterinary college the concentrations of plasma progesterone of the pregnant animals agree favourably with those observed earlier (McEwan \& Whitehead 1980, Rehbinder et al. 1981, Blom et al. 1983).

In the present study a drop in plasma progesterone occurred in all animals from the day of arrival until the day of operation (Figs. $1 \& 2$ ). This drop in plasma progesterone is most likely not a part of the pre-partum hormone changes, but rather due to a change in the animals environment.

A marked but shortlasting increase in plasma progesterone took place in all animals following injection of etorphine/propyonylphenthiazine (Figs. 1 \& 2). Such a shortlasting increase in plasma progesterone has also been observed upon pentobarbitone anaesthesia and surgery in goats (Thorburn \& Schneider 1972) as well as cows (Lindell et al. 1981). The observed increase in plasma progesterone, detectable before surgery, may be due to anaesthesia itself and/or to a delayed effect of the stress introduced by the capturing and the restraint of the animals. In cows, Janowski et al. (1983) found that laparotomy upon local anaesthesia resulted in nearly parallel increases in plasma progesterone and cortisol. On basis of this parallelity they suggested the increase in plasma progesterone to be due to increased production by the adrenals. Since reindeer seem to be very susceptible to mental stress (Rehbinder \& Edqvist 1981), an ACTH mediated increase in progesterone production may be the underlying cause of the post-anaesthetic increase in plasma progesterone observed in the present study. Although pre-anaesthetic values of plasma progesterone were reached before ovariectomy was performed in all animals except 1 in the present study, it is nevertheless not unlikely that stress/anaesthesia may have influenced the effect of ovariectomy and hysterectomy upon plasma progesterone.

The half-life of progesterone is short in animals in which this has been studied. Provided that this also applies to pregnant reindeer, the lack of marked changes in plasma progesterone during the $30-125 \mathrm{~min}$ after ovariectomy should, judged independently of other findings, strongly indicate that most of the progesterone is produced extra-ovarially. Furthermore, hysterectomy, in contrast to ovariectomy, caused a rapid, although varying decline in plasma progesterone (Figs. 2a \& 2b).

Nevertheless, the fact that the progesterone concentrations in ovarian venous blood superceeded those of the peripheral venous blood by a factor of 150 and 400 in 2 of the 
3 animals examined, clearly demonstrated that progesterone is produced by ovarian tissue. The ratios of plasma progesterone in ovarian vein/jugular vein were in these 2 animals of the same order of magnitude as those observed in goats, a species in which progesterone seems to be produced solely by the ovaries (Blom \& Lyngset 1971, Thorburn \& Schneider 1972, Kelly et al. 1982). Further, although plasma progesterone did not decline rapidly upon ovariectomy, the strongly reduced concentrations the following day support the assumption of an ovarian production of the hormone.

In contrast to what should be expected from the rather high disappearance rate of progesterone upon hysterectomy, plasma progesterone values of uterine venous blood from the gravid horn were close to those of jugular venous blood. The last mentioned observation does not point to the placenta as a major source of net progesterone secretion, even when the high blood flow to the uterus during late pregnancy is taken into consideration. However, the continued presence of progesterone in peripheral blood for days after ovariectomy (Fig. 1b), although in low concentrations, as well as the fact that abortion did not take place in 2 of the animals in which only ovariectomy was performed, strongly indicate that progesterone is also produced extra-ovarially. A lack of large concentration differences of progesterone between jugular and uterine venous blood, as in the present study, does not rule out the possibility of the placenta producing moderate amounts of progesterone. Indeed, it has been suggested that species differences in placental production of progesterone are quantitative rather than qualities (Heap \& Flint 1984). In the bovine, a species in which a positive arterio-venous difference across the gravid uterus has not been demonstrable (Comline et al. 1974, Ferrell et al. 1983), perfusion experiments of single placentomas have shown a net secretion of progesterone in prostaglandin $\left(\mathrm{PGF}_{2 \alpha}\right)$-treated cows, but not in controls (Conley \& Ford 1987). On basis of their experiments Conley \& Ford (1987) suggested that the placenta contributes to the maintenance of pregnancy after $\mathrm{PGF}_{2 \alpha}$-luteolysis or ovariectomy in late pregnancy in cows. Wendorf et al. (1983) however, concluded that the adrenals are essential for the maintenance of pregnancy after ovariectomy at day 215 of gestation. Our data give no definite information on the nature of the extra-ovarian source of progesterone in reindeer, but they show its existence also in this species.

In the present study, apparently conflicting results were obtained by analyses of ovarian/jugular venous blood versus the results of ovariectomy. The high ratio ovarian/jugular venous progesterone was not combined with an expected rapid fall in the concentrations of plasma progesterone upon ovariectomy. This discrepancy might be an effect of anaesthesia and/or surgical stress. In addition to the implications of parallel changes in cortisol and plasma progesterone (Janowski et al. 1983), it might be worth mentioning that injection of vasopressin and adrenalin, hormones which are raised in circulatory crises, have been shown to increase plasma progesterone in pregnant women (Fylling 1971). Further, plasma progesterone increases in heavy exercise in humans ( $\mathrm{Ter}$ jung 1974, Bonen et al. 1979, Gravel et al. 1979, Keizer et al. 1980), probably due to decreased liver clearance. Such effects as referred above might have masked an effect on plasma progesterone upon removal of the major production source that might otherwise have been demonstrable. The stress effects, if present, may vary in time and magnitude, and may thus also explain the variations between animals in the changes in plasma progesterone upon hysterectomy. 


\section{References}

Blom AK, Lyngset $O$.: Plasma progesterone levels in goats during pregnancy measured by competitive protein binding. Acta endocr. (Kbh.) $1971,66,471-477$.

Blom AK, Sjaastad $\emptyset V$, Jacobsen E: Plasma levels of progesterone and oestradiol-17 $\beta$ in reindeer (Rangifer tarandus tarandus) during pregnancy. Acta vet. scand. 1983, 24, 287-294.

Bonen $A$, Ling $W Y$, MacIntyre $K P$, Neil $R$, $M c G r a i l ~ J C$, Belcastro $A N$ : Effects of exercise on the serum concentrations of FSH, LH, progesterone and estradiol. Eur. J. appl. Physiol. 1979, 42, 16-23.

Comline RS, Hall LW, Lavelle RB, Nathanielsz $P W$, Silver $M$ : Parturition in the cow: Endocrine changes in animals with chronically implanted catheters in the foetal and maternal circulation. J. Endocr. 1974, 63, 451-47.

Conley $A J$, Ford SP: Effect of prostaglandin $\mathrm{F}_{2 \alpha^{-}}$ induced luteolysis on in vivo and in vitro progesterone production by individual placentomes of cows. J. Anim. Sci. 1987, 65, 500-507.

Diczfalusy $E$, Borell $U$ : Influence of oophorectomy on steroid excretion in early pregnancy. J. clin. Endocr. Metab. 1961, 21, 1119-1126.

Erb RE, Gomes WR, Randel RD, Estergreen Jr. $V L$, Frost $O L$ : Effect of ovariectomy on concentration of progesterone in blood plasma and urinary estrogen excretion rate in the pregnant bovine. J. Dairy Sci. 1967, 51, 420427.

Ferrell CL, Ford SP, Prior RL, Christenson RK: Blood flow, steroid secretion and nutrient uptake of the gravid bovine uterus and fetus. J. Anim. Sci. 1983, 56, 656-667.

Fylling $P$ : The effect of pregnancy, ovariectomy and parturition on plasma progesterone level in sheep. Acta Endocr. (Kbh.) 1970, 65, 273283.

Fylling, $P$ : Vasopressin-induced increase in peripheral plasma progesterone levels during early human pregnancy. Acta Endocr. (Kbh.) 1971, $66,273-282$.
Gavel MJ, Alaghband-Zadeh J, Park DM, Rose $F C$ : Exercise and hormonal secretion. Postgrad. Med. J. 1979, 55, 373-376.

Heap RB: Role of hormones in pregnancy. In: Austin CR \& RV Short (eds.): Reproduction in mammals. Book 3. Hormones in Reproduction. Cambridge Univ. Press. Cambridge 1972, pp. 73-105.

Heap $R B$, Deanesly $R$ : Progesterone in systemic blood and placentae of intact and ovariectomized pregnant guinea pigs. J. Endocr. 1966, 34, 417-423.

Heap RB, Flint APE: Pregnancy. In: Austin CR \& RV Short (eds): Reproduction in mammals. Book 3. Hormonal control of reproduction. Cambridge Univ. Press. Cambridge 1984, pp. 153-194. (2nd ed.)

Jacobsen E, Skjenneberg S: Forsøk med ulike forblandinger til rein. (Experiments with different feeds in reindeer). Meldinger fra Norges Landbrukshøgskole 1979, 58, No. 34.

Janowski $T$, Grunert $E$, Zaremba $W$ : Untersuchungen über den Steroidhormonspiegel bei hochtragenden, im Abstand von 1 bis 2 Tagen zweimal laparatomierten Kuhen der Rasse "Deutsche Schwarzbunte". Zuchthyg. 1983, 18, 193-202.

Keizer HA, Poortman J, Bunnik GSJ: Influence of physical exercise on sex-hormone metabolism. J. appl. Physiol. 1980, 48, 765-769.

Kelly RW, McNatty KP, Moore GH, Ross D, Gibb $M$ : Plasma concentrations of $\mathrm{LH}$, prolactin, oestradiol and progesterone in female red deer (Cervus elaphus). J. Reprod. Fert. 1982, 64, 475-483.

Lindell J-O, Edqvist L-E, Gustafsson B: Oophorectomy during different stages of pregnancy in the cow. Acta vet. scand. 1981, 22, 553-565.

Linzell JL, Heap RB: A comparison of progesterone metabolism in the pregnant sheep and goat: Sources of production and an estimation of uptake by some target organs. J. Endocr. $1968,41,433-438$. 
McEvan EH, Whitehead PE: Plasma progesterone levels during anestrus, estrus, and pregnancy in reindeer and caribou (Rangifer tarandus). In Reimers E, E Gaare \& S Skjenneberg (eds.) 1980, pp. 324-328. Proc. 2nd, Int. Reindeer/ Caribou Symp., Røros, Norway 1979. Direktoratet for vilt og ferskvannsfisk, Trondheim.

Neill JD, Johansson EDB, Knobil E: Patterns of circulating progesterone concentrations during the fertile menstrual cycle and the remainder of gestation in the Rhesus monkey. Endocrinology 1969, 84, 45-48.

Plotka ED, Seal US, Verme LJ, Ozoga JJ: Reproductive steroids in white-tailed deer. IV. Origin of progesterone during pregnancy. Biol. Reprod. 1982, 26, 258-262.

Rehbinder $C, E$ dqvist $L-E$ : Influence of stress on some blood constituents in reindeer (Rangifer tarandus $L$ ). Acta vet. scand. 1981, 22, 480 492.

Rehbinder $C$, Edqvist L-E, Riesten-Arhed $U$, Nordkvist $M$ : Progesterone in pregnant and non-pregnant reindeer. Acta vet. scand. 1981, 22, 355-359.

Schanbacher BD: Radioimmunoassay of ovine and bovine serum progesterone without extraction and chromatography. Endocr. Res. Comm. 1979, 6, (4), 265-277.

Terjung $R$ : Endocrine response to exercise. Exercise Sport Sci. rev. 1974, 7, 153-180.

Thorburn GF, Schneider $W$ : The progesterone concentration in the plasma of the goat during the oestrus cycle and pregnancy. J. Endocr. 1972, 52, 23-36.
Wendorf GL, Lawyer MS, First NL: Role of the adrenals in the maintenance of pregnancy in cows. J. Reprod. Fert. 1983, 68, 281-287.

\begin{abstract}
Sammendrag
Plasma progesterone hos reinsdyr ved ovariektomi og hysterektomi.

Fire tamrein ble ovarieektomert og 3 dyr ble i tillegg deretter hysterektomert 30-70 dager før forventet kalving. Etorphine/propyonylphenthiazineanestesi resulterte $\mathrm{i}$ en forbigånde økning i progesteronnivået $\mathrm{i}$ perifert blod. Før ovarieektomi ble utført hadde progesteronnivået igjen nådd utgangsnivået. Ovarieektomi ga ingen markerte forandringer i plasma progesteronverdiene $\mathrm{i}$ observasjonsperioden (35-120 min). Hysterektomi resulterte $i$ et markant fall i progesteronkonsentrasjon i jugularveneblod i løpet av $60 \mathrm{~min}$.

Progesteronkonsentrasjonen i ovarievenen ble hos 1 dyr funnet å være moderat høyere, og hos de 2 andre 150-400 ganger høyere enn $i$ jugularveneblod.

Til tross for manglende effekt av ovarieektomi på plasmaprogesteronnivået, konkluderes det derfor med at ovariene er et hovedproduksjonssted av progesteron hos drektige reinsdyr.

Hos 1 dyr ble progesteronkonsentrasjonen i uterusveneblod funnet å være tilnærmet lik konsentrasjonen $\mathrm{i}$ jugularveneblod, mens det hos de 2 andre var litt forhøyet. Denne observasjonen, og det forhold at drektigheten ble opprettholdt etter ovarieektomi hos 2 av 4 dyr tyder på at den føtoplacentale enhet bidrar til progesteronproduksjon.
\end{abstract}

(Accepted March 6, 1989).

Reprints may be requested from: $\varnothing$. V. Sjaastad, Dept. of Physiology and Nutrition, Norwegian College of Veterinary Medicine, P. O. Box 8146, Dep., N-0033 Oslo 1, Norway. 